\title{
Working without Words: The Methods of Translating Open Access Technological English Texts into Arabic
}

\author{
AbdelKarim Daraghmah, Ekrema Shehab*, Amani Ashqar \\ AN-Najah University, Dept. Of English, Nablus, Palestine \\ *Corresponding Author:ikrimas@yahoo.com
}

Copyright $@ 2014$ Horizon Research Publishing All rights reserved.

\begin{abstract}
This is a corpus study which demonstrates the difficulties translators encounter when they translate into a target language without an established terminology in the field in question. The purpose of this study is twofold: First, it examines existing methods of translating specialized terminology in technology advertisements/commercials based on three main parameters, namely circulation, recurrence, and audience type. Second, the study proposes certain methods that can be effectively used to render open access specialized technological texts into Arabic for non-specialized audiences. The surveyed texts consist of translations of seventy five of the most visited online website service advertisements. This paper reveals that the text appeal is to be maintained in translation by securing the uninterrupted flow of communication between the service provider and the customer reading the translation. Conformity to the conventions of open access commercial texts and the functionality of those texts remain the main controllers in translating such types of texts.
\end{abstract}

Keywords Technology Commercials Translation, Semantic Deficits, Comprehensibility, Open Access Texts, Translation Strategies

\section{Introduction}

With the more recent consumption of technology services on wider scales, it seems that producers of technological texts no longer limit their consumption to specialists only; many of these texts address ordinary consumers or managers who are non-specialists in the field of technology.

Specialized texts intended for use by technology specialists are marked mainly for the high occurrence of technical terminology in general and the new technological terminology in particular. These novel terms pose a real challenge for the translators when rendering such texts into Arabic. In technical translation, it has been assumed/argued that specialist translators do not need to worry about the simpler needs of the general public since their renderings target specialized audiences who may easily understand their translation but this may not be the case anymore when handling commercial texts (i.e., Ads in the web hosting field) which contain specialized terminologies and which are intended for consumption by non-specialized audiences. In addition to being a specialist in the field, the translator should be well versed in the literary, creative and appellative aspect of his/her working languages.

The common translation wisdom says that Arabic is very often a receptor language when it comes to technology. The discoveries, innovations, and reasoning always happen in a foreign language. Translators, therefore, find it difficult to accommodate the huge number of terminologies which enter the foreign language every day. Arabic is far behind and thus translators find themselves in a situation where they have to deal with a huge semantic deficit in the target language. However, what complicates the issue even further when translating commercials for non-specialists is that translators need to work more carefully on the translation outcome to ensure comprehensibility and appeal for non-specialized users. They are required to use methods other than those which are commonly used in translating English technological texts into Arabic for technology specialists.

Newmark (1981) distinguishes text-types on the basis of language functions. Similarly, in this study, the language functions (persuasive, appealing and promotional) are taken as the decisive elements which distinguish open access texts from those intended for limited access only. Technological texts can be described as open access texts because they are published through the most open-to-public media channels to function as operatively as possible. Usually, they are open access online material which is free of charge and free of copyright and other licensing restrictions. Examples on these texts are commercials/advertisements promoting web services, help documents attached to programs, quotations...etc. In contrast, technological limited access texts are not published through easily accessed media channels, but they are made available only through secured means to function as informatively as possible; they address only the interested audience at an advanced stage of work between the service provider and the customer. Examples on such texts are detailed specification proposals and service contracts. 


\section{Methodology}

This study focuses on analyzing the way English technological texts are rendered into Arabic commercials versions. For this purpose, the researchers surveyed seventy five online commercials promoting web services like website establishment, design, development, programming, and hosting. From the hits accounts, we could discern that these services are published in the most visited websites advertising services for Arab customers. The list of websites is attached as appendix at the end of the article.

The sample texts we collected from these sites consisted of English texts and their Arabic counterparts. In some cases the services were advertised in both English and Arabic. We located and defined the methods used in translating both the purely technological terms which have no Arabic equivalents and the non-technological words for which Arabic translations do exist. The statistical analysis helped identify the translation behavior when translators were working with and without target words.

\section{The Nature of Open Access Texts}

The remarkable development of the technological publishing sites through widespread and easy access media has contributed to the proliferation of various types of technological texts such as advertisements, quotations, user directories and help documents. Thus, texts of website service offering are widely open for the public through television, newspapers, brochures, websites, and direct emails. Open access technology texts are therefore defined as technology texts that advertise web services to any user regardless of his/her education or interest in the field. They are primarily characterized by the frequent use of neologisms due to the rapid developments which create a need for coining new terms to account for new parts, features and/or functions. These neologisms, in this type of texts, are often surrounded by simple, direct and mostly non-specialized language that is used to create a friendly attitude with the audience.

The open access technology texts also exhibit simplicity in language use because they address a widely mixed audience (i.e., users from all walks of life). The commercials are meant to arouse the customer's interest and to build confidence in the product or the service. Thus, persuasion is one dominant trope in these types of texts. The language of promotional materials is marked by using hyperbole, adjectives and adverbs, short sentences, positive ambiguity, weasel words, and imperatives. The producers of such texts may avoid using negatives, present tense, repetition, alliteration, syntactic parallelism, and humor. As a final distinguishing feature, the open access technological texts mix between their technological and promotional aspects in a way that caters for thetheir informative and promotional content.

\section{Open Access Promotional Texts and Translation Challenges}

Almost unanimously, translation scholars advise translators to perform text analysis before they embark on the translation task (Reiss 1976; Werlich 1976; Reiss and Vermeer 1984; Isenberg 1984; Gommlich 1994; Lemke 1988b; Schneider 1991; Nord 2005). It has been argued that the function of the target text plays a significant role in determining the type of translation strategies to be employed. Vermeer's (1984, 2000) Skopos theory which attends to target audience needs focuses on the function of the target text in terms of fidelity and coherence. Accordingly, any translation activity is largely determined by the function of the translation product and the receiver's needs. In translating open access texts, translators find themselves hard pressed to adopt an audience-based (Skopos) approach because they are usually translating to people who are not well versed in technology. Nazzal (2013: 219) gives good reasons for the adoption of Skopos theory in technology translation as he points out that "Arabic language suffers from semantic void when it comes to supplying equivalences for technology terms which puts more of a burden on translators when dealing with inexperienced people in technology." In the same spirit, Farghal and Shunnaq ( 1999: 21) say that "the major problem facing translators at present is terminology standardization and dissemination in science and technology".

The open access texts are multifunctional because they are intended to serve more than one purpose and hence they merge the promotional and the informative functions into one text design. In this regard, Bühlür (1934) classifies text functions into expressive, informative, operative, and technical texts. The technological texts are seen as predominantly informative texts. But this view remains context-independent since open access technological texts can still be used for promotional purposes. In such cases, the translator is guided by the promotional as well as the informative functions.

Hatim and Mason (1990) are more precise when it comes to analyzing the functions of advertisements. They classify text functions into: argumentative, expository, and instructional. The latter is also classified into: instructional texts without options such as contracts and instructional texts with options such as advertisements. In their opinion, advertisements remain argumentative texts that exhibit the features postulated by Reiss (1976) which are: comprehensibility, topicality, memorability, suggestivity, emotionality, language manipulation, and plausibility.

In fact, the majority of the sampled online published commercials/Ads exhibit hybrid text structures that mix between the features of the advertisement and the price quotation text types. Each of these types has distinct genre norms and conventions. Commercials may be seen influential when they are short and economical in structure and in wording. They also may feature simple wording and a 
minimum use of terminology. By contrast, the price quotations are primarily meant to provide the service or product price and the most important details including service packages and the sum amounts for the offered services; thus, quotations may be more complicated in wording and include more specialized technological terms.

Such hybrid text structures can be noticed in the way Mark Host Company designs its commercials to include the factual and the promotional components. By way of illustration, see this extract and its translation:

\section{Target Text}

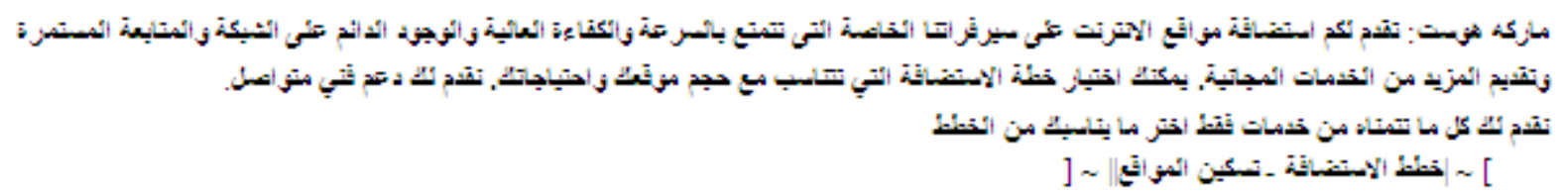

Gloss:

Trademark Host: presents you reception sites internet on our servers special which enjoys speed, high efficiency and permanence existence on the web and follow-up continuous and presents more from services free.

You can choose plan reception which suits with size your location and your needs. We present you support technical continuous .

We present you all you wish from services.

Only choose what suits you from plans.[Plans the reception-hosting the sites]

Source Text : Mark Host: hosts Web sites on our servers, which enjoy high speed, efficiency, the 24-hour support and follow-up services and it provides additional free services. You can choose a hosting plan that suits the size of your site and your needs. We provide you with ongoing technical support. We offer you everything you wish for services; only choose plans which suit/serve you better $\mid \sim$ [Hosting plans - hosting sites]
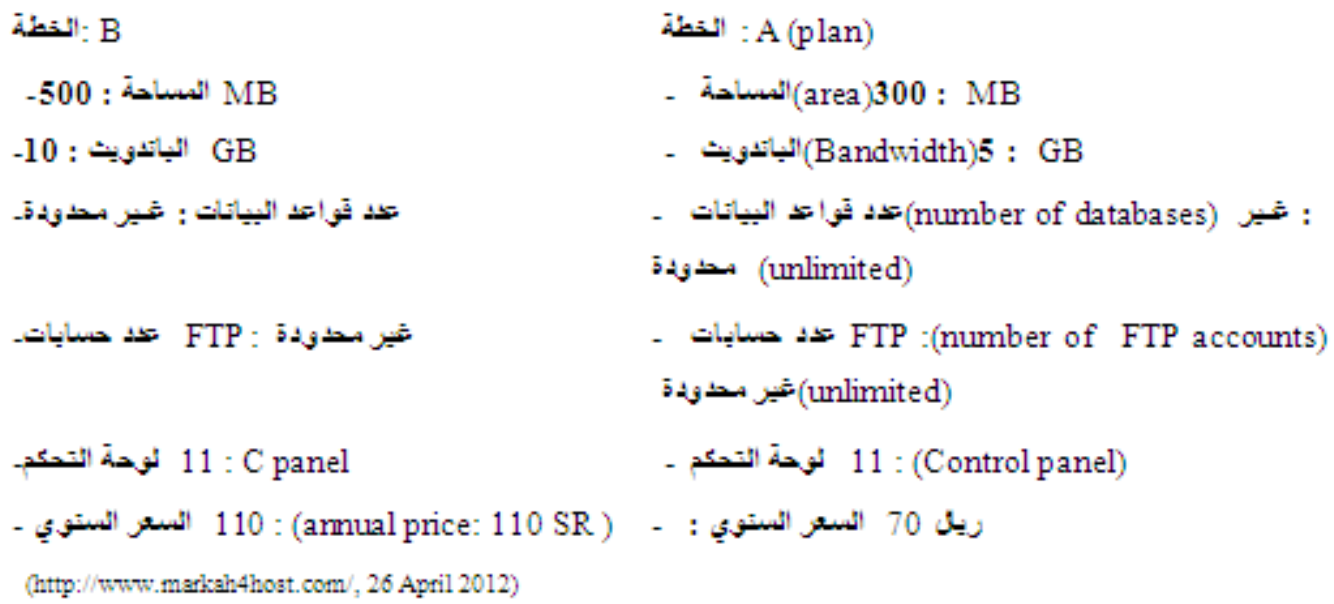

The structures and language in the first part of the text carry the promotional load while the rest of the text shows more features of the price quotation type. It can be noticed that the terms used in the latter part contain terminology from the field of software technology.

The presence of neologisms in openly accessed technological texts complicates the work of the translator due to problems like the lack of equivalence, the lack of consistency in the translations, and the low circulation of terminology. The latter one is very crucial because it makes working from a translation convention almost non-existent. Hence, specialist and/or non-specialist translators dealing with technology translation are faced with a double-edged problem. On the one hand, the translators' familiarity with the jargon which was previously considered a plus may not save them when they render specialized technical texts for non-specialized audiences; they may need to offer explanations rather than translations of some terminologies. Also, the translator's "technical repertoire" which makes his task easier when he renders specialized texts to specialized audiences may not come to his/her rescue when rendering technical promotional texts to people from all walks of life. Specialist translators should acquaint themselves with the emotive elements of language which are needed to produce appealing translations. When the translator of the open access text recognizes its appealing function, he/she is expected to use easy to understand language, especially when dealing with widely circulated terms.

In sum, the main aim of translation is to diminish the linguistic barrier; still, this barrier will not be overcome totally and the message will not be effectively communicated if the translator could not come up with the right strategies to make up for the non-specialized audiences' technology culture deficit as well as the text's appellative nature. 


\section{Open Access Texts and Translation Strategy}

Easy internet access has helped greatly with the emergence of non- specialized audience. It played a notable role in breaking down the conventional trade barriers in a way that created more room for the advent of new markets, i.e. new targeted audience of diverse languages and backgrounds (Leighton, 2001).

Minko O'Hagan (1996) classifies the consumers who are likely to be affected with language differences in the contemporary times into four types: international business people whose activities are scattered around the globe; officials working for the government; scientists who may need to use a particular technical device; and ordinary citizens who use online services for various purposes. O'Hagan also highlights the tendency with service provider advertisers to think globally. Hence, newly formulated texts invade the market of translation. In response to these newly emerging needs for communication, researchers appear to be divided between those who call for adoption and those who prefer adaptation as the most adequate translation strategies. Briefly expressed, the former group calls for adopting a source language word or term intact and using it in the target text (see Shiyab 2010). The latter wants to replace a situation of the source language by an analogous situation of the target language, especially when communicative situations are difficult to understand in the culture of the target language (see Albir 2002).

George Ho (2008) suggests that the translation of website contents requires different techniques from those used in the traditional practices. He maintains that adaptation comes on top of the priority list. Conversely, Nico Wiersema (2005) thinks that the great openness and the constant communication between people made it possible for translators to use the source text terms in the target text. Accordingly, he regards translation in such a case as "excessive translation". His rationale behind this position is that adopting the original terms will provide better understanding and will enrich the target language.

The prevailing spirit of admiration for a postmodern global community would be one justification for using the adoption option. Shiyab (2010) tends to agree with the necessity of adopting and not adapting the new technical and sometimes non-technical foreign terms that result from modernity and globalization. Shiyab supported his view concerning translation in times of globalization with examples about the way foreign technological inventions terms such as computer, laptop, camera among others, are transferred by adoption and not adaptation based on the Arab readership's familiarity with the foreign terms in the age of globalization.

Based on the research work done by these translation scholars, the sections below weigh the actual translator behavior when he/she is confronted with technological neologisms in open access web service advertisements. We examine translation strategies (adoption, adaptation, or a combination of these two strategies) in such types of translations. The translators will have to make sure that understanding is not blocked by the frequent use of new technical terms. When comprehensibility is compromised, the most neatly designed advertisements will neither be appealing nor beneficial. Thus, comprehensibility and appeal are considered two key criteria in measuring the success of the promotional technological text translations.

\section{Arabicization (i.e., adapting elements of a foreign language to the phonetic or structural pattern of Arabic) or Translation?}

\subsection{The Purely Technological Terms}

It has been noticed that the online advertisements include purely technological terms that may sound strange to a non-specialized audience. In many cases, translators find themselves in a situation where they have to make up for the problem of non-equivalence or to select from among equivalent options that are either weak or not so consistent.

Table 1. The purely technological terms from the surveyed sample

$\begin{array}{lll}\text { English term } & \text { Translated term } & \text { Arabicized term } \\ \text { Server } & \text { نطاق (gloss: servant) } & \\ \text { Dيرف (gloss: realm) } & \text { خومين (gloss:domain) }\end{array}$

When it comes to transferring and/or translating the English term "server", most of the commercials use the Arabicized word "سيرفر" (server) in a way that communicates its meaning sufficiently since this word is most familiar and most circulated in computer technology. Thus it scores a higher frequency $(67 \%)$ in the sample commercials. On the other hand, "خادم" (lit.servant) has been infrequently used ( $33 \%$ of the actual occurrence) on its own as an Arabic equivalent. In only a few cases, the advertisement supplies the original English term "server" or the transliterated " "خيرفر" along with the translated "خادم".

It is often the case that the Arabicized terms gain wider circulation than their Arabic counterparts. For example, the Arabicized term "سيرفر is much more acceptable and more widely used as a result of being the one term used by the specialized technicians in their day to day contact with their customers. As a result, its circulation is enhanced and the circulation of its Arabic counterpart is weakened.

In a similar fashion, it has been found that commercial writers use the Arabicized term "دومين (domain) in 53\% of the studied commercials. The literal translation "نطاق" (lit. realm) is detected in $18 \%$ of the cases while both terms exist simultaneously in $29 \%$. In other words, the transference of "domain" is classified under the same category as server where the Arabicized loan translation is more circulated. 
This practice of using the loan word instead of the Arabic translation can be in part ascribed to the fact that technological terms are urgent and cannot await translation. Once the term enters the market, it is given an Arabic name (usually the Arabicized name). This name becomes most familiar to the public and consequently the most circulated one. Any subsequent accredited translations offered later by specialists in the Arab Academy for Arabicization do not usually gain currency among the average users.

\subsection{The Non-Technological Terms}

Online advertisements also include non-technological terms where Arabic does not suffer from a semantic deficit. Table 2 shows the non-technological terms from the surveyed sample.

Table 2. non-technological terms from the surveyed sample

\begin{tabular}{|c|c|c|}
\hline English term & Translated term & Arabicized term \\
\hline Hosting & $\begin{array}{l}\text { استضافة / تسكين } \\
\text { (gloss: } \\
\text { hosting/reception) }\end{array}$ & هوست (host) \\
\hline Application & تطبيق (application) & أبلكيشن (application) \\
\hline Back up & دعم (support) & باكت أب (back up) \\
\hline Banner & $\begin{array}{l}\text { الثريط الإعلاني (advertising tape) } \\
\text { (a)rising }\end{array}$ & بنر (banner) \\
\hline
\end{tabular}

In the majority of cases, the English term "hosting" was translated literally as"تسكين or "تسكين" "استضافة" is found to be used infrequently in the studied commercials while "استضافة" is the circulated Arabic equivalent for the English term. Further, very rare occurrences have been found for the "هوست" Arabicized word "هوست in writing. It is noticed that is transliterated mainly when referring to company names such as: "مكتب هوست لخدمات الويب المتكاملة" (gloss: Office Host to Services the Web the Complete), (lit. Host Office for

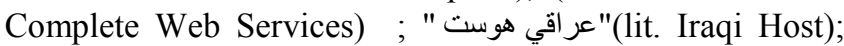

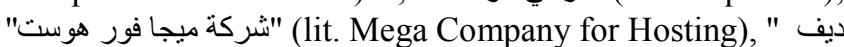

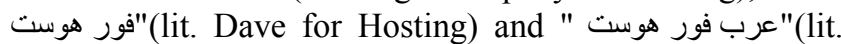
Arab for Hosting). In these cases, it would be expected to find these titles translated into " مكتب الاستضافة لخدمات الانترنت "المتكاملة" (gloss: Office the Reception to Services the Internet the Complete), (lit. Host Office for Internet Services); "العر اقي للاستضافة" (gloss: the Iraqi for Reception), (lit. Iraqi for Hosting); "شركة ميجا للاستضافة" (gloss: Company Mega for "ديف للاستضافة" "2oception),(lit. Mega Company for Hosting) (gloss: Dave for Reception), (lit. Dave for Hosting); " عربف "ل "لاستضافة" (gloss: Arab for Reception),(lit. Arab for Hosting), respectively. However, this was not the case in the published Arabic versions. A likely explanation for such consistency in using the Arabicized term is that translators tend to transliterate the foreign technical terms when they appear in company names because translating them could result in having two distinct names for the same company. Furthermore, like in the cases of names for fashion shops, restaurant and hotel chains, and the food industry, English is still considered more prestigious than Arabic.
Statistically, the Arabic translation "استضافة" is used more in the commercials of companies. It was used in $67 \%$ of the actual occurrences in the sample commercials, while "تسكين" appeared $20 \%$ of the times. Further, it has been found that commercial writers resorted to using both "تسكين و استضافة in $13 \%$ of the actual occurrences. Six companies used both "تسكين" in their promotional texts linked with the coordinating conjunction "و" (and). This indicates that using the literal translation "تسكين" has gained less circulation for it is used less frequently than the other choice.

The statistics related to term's frequency show that some of the Arabic technological terms related to web services are frequently used along their English counterparts in the same commercial. The word "application" in the original English texts appears in the Arabic texts either through Arabicization as "نطبيق" or through translation as "أبكيشن". The term "أبلكيشن" appeared in $36 \%$ in the studied commercials; similarly, "تطبيق" represented 36\%. But, both options were used in the same commercial in $28 \%$ of the promotional texts. In this case both the Arabicized and the translated terms are competing to gain acceptability amongst the public.

In this regard, Google, the most popular among web service providers, publishes its Arabic version of the privacy policy using the translated term "تطبيق" (application) without the transliterated "أبكيشن" (application) but the document uses the abbreviated term "Google Apps" only once at the beginning. This single use of the abbreviated form (Apps) is enough to guarantee that no mixing up of terms will happen; apparently, as a translation policy, the Google team prefer using the translated term. Dr. Fayeq Owis, the director of Arabicization unit and the Arabic content at Google, confirmed this conclusion when the researchers informally interviewed him during his visit to An-Najah University campus in June 2012. Dr. Owis noted that Google adopts a specific strategy to promote Arabic translation by using the translation together with the English version of the term only in the first occurrence; the subsequent occurrences of the same term only give the Arabic version. By using this coupling-on-the-first-occurrence strategy, Google does not compromise comprehensibility; nonetheless, it will introduce the target reader to the Arabic translation and thus promote it through recurrence. Apparently, through recurrence, the term "تطبيق" has gained much circulation to the extent that it is used in announcements and advertisements that target non-specialized users.

To our surprise, the term "Back up" appears in the majority of the studied material in its Arabicized version" باك أب . To be precise, it was used in $73 \%$ of the surveyed commercials; while the translated term (دعم/ listed above) is weaker in recurrence $(18 \%)$ and is scarcely used together with the Arabicized version (9\%).

Another term that behaves in a similar fashion is the term "Banner". Sixty percent of the studied materials promoting web services employ the Arabicized version of the term as "بنر" (banner); while $27 \%$ of the service providers use the translation as "الثريط الإعلاني" (lit. advertising banner) and only $13 \%$ use both versions. 
In relation to this case, it was also noticed that there is a lack of consistency concerning the Arabic rendering of the term because various realizations appear in the Arabic texts such as: "بنر إعلاني" (advertising banner), "شريط إعلاني". The translation practice appears to be inconsistent since it is natural in Arabic to use "شريط" (banner) with the clarifying adjective "بإعلاني","(advertising) while it is unjustified to resort to linguistic code switching in "بنر إعلاني". Like in the case of application, such inconsistency, which happens despite the availability of an Arabic equivalent, can be attributed to the absence of a translation policy which promotes Arabic translations.

Generally speaking, the collected data reveals that the Arabicized terms are more acceptable and widely circulated than the translated ones. The overall statistics show that $66 \%$ of the English original terms are circulated by their Arabicized versions while the translated and the coupled versions amount to only $17 \%$ each. When the Arabicized and the translated versions are in competition, the life cycle for each is determined by several factors; the speed and the vigor of the efforts exerted by the translation and Arabicization bodies to promote the term amongst translators and copywriters; another factor that might positively contribute to the proliferation of Arabic translations is the national policy of the individual Arab countries. In some countries like Syria, for example, Arabic is considered one crucial component of the national identity; a thing that works to the advantage of the translated versions and to the disadvantage of the Arabicized ones. The Syrian websites constituted approximately to $19 \%$ of the study sample (see appendix 2 for a list of Syrian websites); 69\% of those Syrian websites employ Arabic translations while only $31 \%$ provide the translation together with the Arabicized version of the technological terms.

Many other countries like Egypt and Jordan are much more tolerant towards the integration of foreign technological terms.

\section{The Hybrid Language and Hybrid Syntax}

With reference to the hybrid nature of the promotional texts, this section discusses the functions of the hybrid syntax and the hybrid language combinations.

\subsection{The Hybrid Language}

The language used in authorizing this type of commercials is of mixed nature. English and Arabic terms are used in the same line. In many cases, such combinations come for a basic informative function. In other places, part of the technological text is rendered into Arabic (regardless of whether it comes in translation or in an Arabicized form) and the rest of the text is kept in its original English language for the absence of any equivalence. An example would be the following excerpt from an advertisement authorized by Al-Mas's server advertisement and is addressed to non-specialized company managers. The technical components are translated into Arabic while the detailed specifications are given in English:

Text 1. Coupling Arabic and English versions

\begin{tabular}{|c|c|}
\hline English technological terms & Coupling Arabic and English translation \\
\hline Dell PowerEdge 1950 chassis (1u rackmount) & الخادم هيكل (server structure) \\
\hline $\begin{array}{l}\text { Dual Intel Xeon Quad Core E5335 at } 2 \mathrm{GHz} \text { (Clovertown) (processor } \\
\text { speed) }\end{array}$ & سرعة المعالج (processor speed) \\
\hline 8M Cache 1333MHz FSB & كاش المعالج (cache processor) \\
\hline
\end{tabular}

(www.al-mas.org, 29 Feb. 2012)

The reason behind using the English terms and their Arabic counterparts opposite each other is to avoid any likely confusion. Confusion may result when the user is not familiar with either term. The case of coupling Arabic and English versions can be exemplified by Al-Ayyam Net Company for web services:

Text 2. Coupling Arabic and English versions

Half Page: الثريط الإعلاني العمودي الرئيسي (gloss: the Tape Advertising the Vertical the Main) (lit. Main vertical advertising banner)

Leader Border1: border or banner الشريط الإعلاني الرئيسي (gloss: the Tape Advertising the Main) (lit. Main advertising banner) Leader Border: الثريط الإعلاني السفلي الإنير (gloss: The Tape Advertising the Bottom) (lit. Lower advertising banner)

Left Square: الثربط الإعلاني المربع الأيسر (gloss: the Tape Advertising the Square the Left) (lit. Left Square advertising banner) News Banner: الشريط الإعلاني النصفي الإني (gloss: the Tape Advertising the Half) (lit. Half advertising banner)

Top Banner: الثريط الإعلاني العلوي (gloss: the Tape Advertising the Top) (lit. Top advertising banner)

(www.alayyam.com, 23 April 2012)

It is worth noting that this strategy will help promote the Arabic translation of the original English. It helps the newly coined Arabic terms to gain circulation. 


\subsection{The Hybrid Syntax}

The study sample reveals a group of technological terms that have been integrated syntactically into Arabic. The Arabicized terms are linked to the Arabic plural feminine inflection in Arabic "آت such as:

$\begin{array}{ll}\text { English technological term } & \text { Arabicized plurals } \\ \text { Hosting } & \text { استضافات (dosting services) } \\ \text { Domain } & \text { دومينات (domains) } \\ \text { Banner } & \text { (بكيثنات (banners) } \\ \text { Application } & \text { (applications) } \\ \text { Server } & \end{array}$

Other examples show syntactic integration in which the Arabicized term is linked to the Arabic second person inflectional morpheme "ك" (K) such as the case of the commercial published on Traidnt promotional website. The insertion of "k" is done for purely promotional purposes in order to reduce the distance between customer and service provider.

(gloss: for first ten orders...your domain by 25 SR only) (lit. Your domain is only for SR 25! For the first ten orders!

(gloss: speed up booking your server free!

(lit. Ask for your server as fast as you can for free)

(www.traidnt.net/vb/traidnt1967668/, 20 April 2012)

\section{Results}

By using online published commercials/advertisements promoting web services as its main source of data, the study has encompassed the translation behavior, the target text syntactic and semantic features, and the growing preference among commercial designers to localize foreign terms in Arabic.

Confronting the great influx of foreign terminology, Arabic commercial writers use either Arabicization or translation. Occasionally, the English term and its Arabic counterpart appear together in the translated text. However, the Arabicized terms are more popularly used in the translated versions when translators handle purely technical terms. The preference for this technique can be attributed to the fact that Arabic suffers a semantic deficit in the field of information technology and software industry in general. When translators resort to coining new terms, it is often the case that these terms fail to circulate on wider scales and they usually turn into stock neologisms.

Pinchuk (1977) argues that when accuracy and end user convenience are in conflict, the translator must resolve the conflict by giving priority to user convenience. This principle may imply that when faced with the options between Arabicization and translation, audience convenience should be the decisive and the overruling factor. The non-specialized audience is in need for more understandable and familiar promotional technological texts. The need for familiarity and easy comprehension becomes the guiding principle for the copy writers who wish to respect the Minimax principle when writing to satisfy consumers.

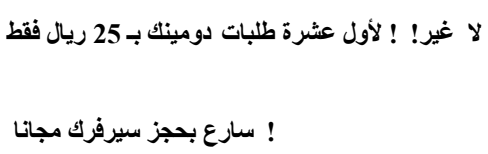

This principle regulates effort and reward in the sense that in choosing between a number of solutions to a given problem, the translator ultimately settles for that solution which promises maximum effect for minimal effort on the part of the reader (see Hatim 2004 ,pp.241-242). Accordingly, open access text translators and copy writers are advised to combine familiar Arabicizations with unfamiliar translations.

The late and less than satisfactory efforts exerted by the Coordination Bureau of Arabicization in Rabbat, affiliated with the Arab League for Education, Culture and Sciences Organization (ALECSO), and the currently chaotic conditions of translation and transference of technological neologisms into the Arab countries, have all led to a situation where the Arabicized terms are now integrated morphologically and syntactically in the Arabic texts and are gaining more circulation and acceptability amongst the public.

\section{Conclusion}

If we wish to reverse the translation status quo in this domain, Google's policy to enhance the online Arabic content may be one good example to follow. It is estimated that the online Arabic content amounts only to $1.5 \%$ of the total online content. To increase this percentage when dealing with neologisms, the Google teams use the Arabicized terms only in the first occurrence while the second or third appearance for the same term in the same document is given in Arabic. In fact, using the Arabicized 
terms and the translated ones would make for a sound and more consumer friendly strategy in promotional technology texts. Over time, the Arabic terms will gain more circulation and this would gradually reduce the semantic deficit in Arabic language.

\section{Appendix 1}

Websites from various Arab countries visited between 3 Apri - 16 May 2012:

http://www.ahgez.com/

http://www.alayam.com/mobile/announce.aspx

http://www.al-mas.org/home/?section=domainsnames

http://www.al-saudia.org/newspapers.php?newspaperid $=10$

645

http://www.alshrqy.com/vb/alshrqy9182

$\mathrm{http}: / / \mathrm{www}$.altasjeel.com/

http://www.arabiko.com/advert

http://www.arabnas.com/

http://www.bannersway.com/services.php?cat=1

http://www.bayt.com/ar/affiliates/links/banner-ads/

http://www.bdr130.net/vb/t396472.html

http://www.belajfa.blogspot.com/2011/12/start-logic.html

http://www.clients.orkied.com/announcements.php?id=1

http://www.dr-ho.org/

http://www.elestdafa.com/servers.html

http://www.expoarabia.com/ar/list.aspx?t=p\&cat_id=1877\&

$\mathrm{p}=1$

http://www.farah.t6wr.com/?p=4

http://www.fonon4host.com/portal/

http://www.foody-des.com/offers22.html

http://www.foody-des.com/offers28.html

http://www.google.ps/imgres?q=\%D8\%A8\%D9\%86\%D8\%

B1\%D8\%A7\%D8\%AA+\%D8\%A7\%D8\%B9\%D9\%84\%D

8\%A7\%D9\%86\%D9\%8A\%D8\%A9\&start=195\&hl=en\&sa

$=$ X\&biw $=1680 \& b i h=949 \&$ tbm $=$ isch \&prmd $=$ imvnsfd \&tbni

$\mathrm{d}=$ Dc4EhnnsI39S2M:\&imgrefurl=http://www.mtwer.com/v b/t91216.html\&imgurl=http://www.cdegypt.com/offers/1.jp $\mathrm{g} \& \mathrm{w}=700 \& \mathrm{~h}=349 \& \mathrm{ei}=\mathrm{v} 8$ A9UPn3BoaZ0QWkj4D4AQ\&zo om $=1 \&$ iact $=$ hc \&vpx $=163 \& v p y=436 \&$ dur $=149 \&$ hovh $=158$ $\&$ hovw $=318 \&$ tx $=214 \&$ ty $=98 \&$ sig $=1161625516670811451$ $63 \&$ page $=5 \&$ tbnh $=101 \&$ tbnw $=203 \&$ ndsp $=51 \& v e d=1 \mathrm{t}: 429$, $\mathrm{r}: 8, \mathrm{~s}: 195, \mathrm{i}: 31$

http://www.google.ps/imgres?q=\%D8\%A8\%D9\%86\%D8\% B1\%D8\%A7\%D8\%AA+\%D8\%A7\%D8\%B9\%D9\%84\%D 8\%A7\%D9\%86\%D9\%8A\%D8\%A9\&start=882\&hl=en\&sa $=$ X\&biw $=1680 \& b i h=949 \&$ tbm $=$ isch $\&$ prmd $=$ imvnsfd \&tbni $\mathrm{d}=$ bo $6 \mathrm{hVM} \quad 5 \mathrm{~s} 5 \mathrm{rM}: \&$ imgrefurl=http://www.traidnt.net $/ \mathrm{v}$ b/traidnt1480184/\&imgurl=http://www.traidnt.net/vb/custo mavatars/avatar71056 2.gif \&w=128\& $\mathrm{h}=134 \&$ ei=-sg9UIi7 BYrD0QXTqIDoBg\&zoom $=1 \&$ iact $=\mathrm{hc} \& v p x=1305 \& v p y=$ $715 \&$ dur $=664 \&$ hovh $=107 \&$ hovw $=102 \&$ tx $=75 \&$ ty $=71 \&$ sig $=116162551667081145163 \&$ page $=19 \&$ tbnh $=107 \&$ tbnw $=1$ $02 \&$ ndsp $=50 \& v e d=1 \mathrm{t}: 429, \mathrm{r}: 32, \mathrm{~s}: 882, \mathrm{i}: 106$

http://www.google.ps/imgres?q=\%D8\%A8\%D9\%86\%D8\% B1\%D8\%A7\%D8\%AA+\%D8\%A7\%D8\%B9\%D9\%84\%D
8\%A7\%D9\%86\%D9\%8A\%D8\%A9\&start=395\&hl=en\&sa $=$ X\&biw $=1680 \& b i h=949 \& \mathrm{tbm}=$ isch \&prmd $=$ imvnsfd\&tbni $\mathrm{d}=$ Oqgc-uuj6VwlrM:\&imgrefurl=http://www.mtwer.com/v b/t99600.html\&imgurl=http://img05.arabsh.com/uploads/im age $/ 2012 / 03 / 08 / 09314 \mathrm{~d} 4360 \mathrm{fb}$.png $\& \mathrm{w}=660 \& \mathrm{~h}=250 \& \mathrm{ei}=\mathrm{pc}$ U9UL72IuLW0QXnhICoDQ\&zoom $=1 \&$ iact $=$ hc \&vpx $=936$ $\& v p y=458 \&$ dur $=2165 \&$ hovh $=138 \&$ hovw $=365 \&$ tx $=263 \&$ ty $=99 \&$ sig $=116162551667081145163 \&$ page $=9 \&$ tbnh $=73 \&$ tb $\mathrm{nw}=193 \& n d s p=48 \& v e d=1 \mathrm{t}: 429, \mathrm{r}: 12, \mathrm{~s}: 395, \mathrm{i}: 43$

http://www.hvips.com/domain.html http://www.i3rab.com/blog/archives/5313 http://www.iraqsg.com/get-15258.html http://www.iraqsg.com/get-16388.html http://www.itqanbs.com/website-design.html http://www.iweb-serv.com/ http://www.jeddahbikers.com/vb/t57615.html https://www.khamsat.com/business/4998-\%D8\%AA\%D8\% B5\%D9\%85\%D9\%8A\%D9\%85-3-\%D8\%A8\%D9\%86\%D 8\%B1\%D8\%A7\%D8\%AA-\%D9\%84\%D9\%85\%D9\%88\% D9\%82\%D8\%B9\%D9\%83-\%D8\%AB\%D8\%A7\%D8\%A8 \%D8\%AB\%D8\%A9-\%D8\%A3\%D9\%88-\%D9\%85\%D8\% AA\%D8\%AD\%D8\%B1\%D9\%83\%D8\%A9-\%D8\%A8\%D 8\%A7\%D9\%84\%D8\%A3\%D8\%AD\%D8\%AC\%D8\%A7\% D9\%85-\%D8\%A7\%D9\%84\%D8\%AA\%D9\%8A-\%D8\%A A\%D9\%86\%D8\%A7\%D8\%B3\%D8\%A8\%D9\%83 http://www.masaserv.co/ http://www.misrstars.com/vb/showthread.php?t=60775 http://www.moqe3.com/ http://www.mouse4host.com/ http://www.mtwer.com/vb/t101985.html http://www.netmasr.net/web.html http://www.pcintv.com/forums/showthread.php?t=36804 http://www.q8egy.maktoobblog.com/59/\%D8\%AA\%D8\% B7\%D8\%A8\%D9\%8A\%D9\%82-\%D8\%A7\%D9\%84\%D8 \%A3\%D9\%8A\%D9\%81\%D9\%88\%D9\%86-\%D8\%A7\%D 8\%A8\%D9\%84\%D9\%83\%D9\%8A\%D8\%B4\%D9\%86-\% D9\%84\%D9\%84\%D8\%A3\%D9\%8A\%D9\%81\%D9\%88\% D9\%86-iphone/

http://www.rawabetvb.com/vb/rawabet271535/

http://www.rwc.ae/

http://www.sandoq.com/freeads.asp?title $=\% \mathrm{C} 7 \% \mathrm{CD} \% \mathrm{CC} \%$ D2-\%C7\%EC-\%CE\%D8\%C9-\%C7\%D3\%CA\%D6\%C7\% DD $\%$ C9-\%E6\%C7\%CD\%D5\%E1-\%DA\%E1\%EC-\%CF\% E6\%E3\%ED\%E4-\%CD\%E3\%E1\%C9-\%C7\%E1\%C7\%DA $\% \mathrm{E} 1 \% \mathrm{C} 7 \% \mathrm{E} 4 \% \mathrm{C} 7 \% \mathrm{CA}-\% \mathrm{DD} \% \mathrm{EC}-\% \mathrm{C} 7 \% \mathrm{E} 1 \% \mathrm{DD} \% \mathrm{ED}$ $\% \mathrm{D} 3 \% \mathrm{C} 8 \% \mathrm{E} 6 \% \mathrm{DF}-\% \mathrm{E} 3 \% \mathrm{CC} \% \mathrm{C} 7 \% \mathrm{E} 4 \% \mathrm{C} 7-\% \mathrm{E} 1 \% \mathrm{E} 1 \%$ $\mathrm{C} 8 \% \mathrm{ED} \% \mathrm{DA} \& \mathrm{c}=12 \& \mathrm{id}=280313$

http://www.sandoq.com/freeads.asp?title $=\% \mathrm{CA} \% \mathrm{D} 5 \% \mathrm{E} 3 \%$ ED $\%$ E3-\%E3\%E6\%C7\%DE\%DA-\%C7\%E4\%CA\%D1\%E $4 \% \mathrm{CA}-\%$ E6\%CF\%E6\%E3\%ED\%E4\%C7\%CA-\%E6\%CA $\% \mathrm{D} \%$ E6\%ED\%DE-\%E1\%E3\%E4\%CA\%CC\%DF-\%E1\% $\mathrm{E} 1 \% \mathrm{C} 8 \% \mathrm{ED} \% \mathrm{DA} \& \mathrm{c}=12 \& \mathrm{id}=259771$

http://www.sh3a34host.org/vps.php http://www.sogarab.com/top_webhosting.php http://www.spotech.net/?cat=4 http://www.swalif.net/softs/swalif65/softs271066/ http://www.traidnt.net/vb/traidnt1967668/ 
http:/www.traidnt.net/vb/traidnt367536/

http://www.traidnt.net/vb/traidnt375901/

http://www.trncat.com/Design/Price/

http://www.ultimateserv.com/domains/

http://www.un4web.com/design.html

http://www.uowhost.com/announcements.php?id=8

http://www.vb.4heronline.net/t7637-post13481.html

http://www.visionhosts.com/

http://www.wdesigners.org/

http://www.worldforhost.net/

http://www.world-gd.com/t155801.html

\section{APPENDIX 2}

The Syrian websites:

http://www.directory.tayob.com/show29638.html

http://www.ehjuz.com/domain.php

http://www.lelnas.com/Items.aspx?ItemId=65162

http://www.nis-me.com/website-hosting

http://www.searchinsyria.com/ar/\%D8\%AA\%D9\%81\%D8

\%A7\%D8\%B5\%D9\%8A\%D9\%84/7263/\%D8\%B3\%D9\%8

A\%D8\%B1\%D9\%8A\%D8\%A7\%D9\%86-\%D9\%85\%D9\%

88\%D9\%86\%D8\%B3\%D8\%AA\%D8\%B1-\%D9\%84\%D8

$\%$ AE $\%$ D8\%AF\%D9\%85\%D8\%A7\%D8\%AA-\%D8\%A7\%

D9\%84\%D8\%A5\%D9\%86\%D8\%AA\%D8\%B1\%D9\%86\%

D $8 \%$ AA

http://www.searchinsyria.com/ar/\%D8\%AA\%D9\%81\%D8

\%A7\%D8\%B5\%D9\%8A\%D9\%84/7768/\%D8\%B4\%D8\%

B1\%D9\%83\%D8\%A9-\%D8\%A3\%D8\%AA\%D9\%85\%D8

$\%$ AA

http://www.searchinsyria.com/ar/\%D8\%AA \%D9\%81\%D8

$\%$ A7\%D8\%B5\%D9\%8A\%D9\%84/5593/\%D9\%84\%D8\%A

7\%D9\%85\%D8\%A7\%D8\%B1-\%D8\%A7\%D8\%B3\%D8\%

AA $\%$ D $8 \%$ AF $\%$ D9\%8A $\%$ D9\%88

http://www.searchinsyria.com/ar/\%D8\%AA\%D9\%81\%D8

\%A7\%D8\%B5\%D9\%8A\%D9\%84/1351/\%D8\%AE\%D8\%

AF\%D9\%85\%D8\%A9-\%D8\%AA\%D8\%B5\%D9\%85\%D9

$\% 8 \mathrm{~A} \% \mathrm{D} 9 \% 85-\% \mathrm{D} 9 \% 85 \% \mathrm{D} 9 \% 88 \% \mathrm{D} 8 \% \mathrm{~A} 7 \% \mathrm{D} 9 \% 82 \% \mathrm{D} 8$

\%B9-\%D8\%A7\%D9\%84\%D8\%A5\%D9\%86\%D8\%AA $\%$

D8\%B1\%D9\%86\%D8\%AA

http://www.searchinsyria.com/ar/\%D8\%AA\%D9\%81\%D8

$\%$ A7\%D8\%B5\%D9\%8A\%D9\%84/168/\%D8\%A7\%D9\%84

\%D8\%AC\%D9\%85\%D8\%B9\%D9\%8A\%D8\%A9-\%D8\%

A7\%D9\%84\%D8\%B9\%D9\%84\%D9\%85\%D9\%8A\%D8\%

A9-\%D8\%A7\%D9\%84\%D8\%B3\%D9\%88\%D8\%B1\%D9

\%8A\%D8\%A9-\%D9\%84\%D9\%84\%D9\%85\%D8\%B9\%D

9\%84\%D9\%88\%D9\%85\%D8\%A7\%D8\%AA\%D9\%8A\%

D8\%A9

http://www.souriahost.com/

http://www.sws-syria.com/ar/\%D8\%AE\%D8\%AF\%D9\%85

$\%$ D8\%A7\%D8\%AA-\%D9\%85\%D9\%88\%D8\%A7\%D9\%8

2\%D8\%B9-\%D8\%A7\%D9\%84\%D8\%A7\%D9\%86\%D8\%

AA $\%$ D $8 \%$ B $1 \%$ D $\% \% 86 \%$ D $8 \%$ AA

http://www.syria-cars.com/adver.htm

http://www.syriandomain.com/register/

http://www.syrian-host.com/ http://www.tld.sy/index.php/news/45-price

http://www.web.sptechs.com/www.zad.sy/

\section{REFERENCES}

[1] Albir, A. (2002). “ Translation techniques revisited: a dynamic and functionalist approach." Meta 47 (4):498-512

[2] BüHLER, K. (1934): Sprachtheorie: Die Darstellungsfunktion der Sprache. Jena: Gustav Fischer.

[3] Farghal, M. and Shunnaq, A. (1999). Translation with reference to English and Arabic texts. Irbid: Dar Al Hilal for Translation.

[4] Gommlich, K. (1994): Text typology and translation-oriented text analysis. In: S. Wright \& L.Wright, "eds." Scientific and technical translation. Philadelphia: John Benjamins Publishing Company, 175-176.

[5] HATIM, B. (2004) 'The translation of style: linguistic markedness and textual evaluativeness', Journal ofApplied Linguistics (1)3: 229-46

[6] Hatim, B. and Mason, I. (1990): Discourse and the Translator. London: Longman.

[7] Ho, G. (2008): Globalization and translation: Towards a paradigm shift in translation studies. Saarbrücken: VDM Verlag.

[8] ISENBERG, H. (1984): Texttypen als interaktionstypen. Zeitschrift für Germantistik (5)2: 261-70.

[9] LEIGHTON, H. (2001): Brave new world: Globalization, internationalism and localization. Language update (34)2: 12 .

[10] LEMKE, J. (1988): Text Structure and Text Semantics. In R. Veltman and E. Steiner, "eds."Pragmatics, Discourse, and Text: Systemic Approaches. London: Pinter.

[11] NeWMARK, P. (1981): Approaches to Translation. Oxford: Pergamon Press.

[12] Nazzal, A. (2013): “Vermeer's Skopos's Theory: As a paradigm Change." Arab World English Journal (2) 2013.pp.212-223

[13] NORD, C. (2005): Text analysis in translation: Theory, methodology, and didactic application of a model for translation-oriented text analysis. Amsterdam: Rodopi.

[14] O'Hagan, M. (1996): The coming industry of teletranslation: Overcoming communication barriers through telecommunication topics in translation. Adelaide: Multilingual Matters LTD.

[15] PINCHUK, I. (1977): Scientific and technical translation. London: André Deutsch.

[16] REISS, K. (1976): Texttyp und Übersetzsungsmethode. Kronberg: Scriptor.

[17] RIESS, K. and Vermeer, H. (1984): Grundlegung einer 
allgemeinen Translationstheorie. Tübingen: Niemeyer.

[18] SCHNEIDER, A. (1991): Texttypen und textsorten in der Übersetzung. Fremdsprachen 4: 36-38.

[19] SHIYAB, S. (2010): Globalization and its impact on translation. In S. Shiyab, M. Rose, J. House \& J. Duval , "eds." Globalization and aspects of translation.
Newcastle: Cambridge Scholars Publishing, 1-10.

[20] Werlich, E. (1976): A text grammar of English. Heidelberg :Quelle and Meyer.

[21] WIERSEMA, N. (2004): Globalisation and translation a discussion of the effect of globalisation on today's translation.Translation Journal (8) 1:1-5. 